\title{
Globalization and the Logic of Participation: Unions and the Politics of Coalition Building
}

\author{
Lowell Turner
}

Global liberalization is driving a 'logic of participation', for firms and unions alike. Economic pressures drive managers to innovate across a range of possibilities, from outsourcing and union busting to work reorganization and labor-management partnership. Those same pressures, reflected largely through the strategic choices of employers, also force unions to innovate - from concession bargaining and cooperation to coalition building and international solidarity. Because employers are increasingly tempted by strategies that seek to weaken or marginalize unions, sustained participation for unions arguably requires a new period of activist mobilization.

This article explores one significant component of renewed labor mobilization: union coalition building. Based on a case study of coalition efforts in the United States between the United Steelworkers and the Sierra Club from 1999-2004, concepts and causal linkages are suggested for broader analysis. Research findings presented here indicate the following causal processes at work: union strategies, defining moments and spillover combine to drive coalition building processes that include events, campaigns and institution building - ranging from local to national and global levels. Beyond this US-based case, a framework for cross-national comparative analysis is also suggested.

The current global drive toward economic liberalization generates pressures in all directions, from public policy and the natural environment to employers and unions to other social actors and citizens everywhere. Impacts range from living standards and working conditions to the possibilities for economic, social and political participation. In many ways, the latter are increasingly suppressed as global forces move beyond the influence of any but G7 governments and multinational corporations. Paradoxically, however, there is also a 'logic of participation' rooted in economic change, a logic that pressures both employers and unions and, by extension, opens up new possibilities for democratic voice in global, national and local political economies.

In the face of intensified competition and tight fiscal and monetary policy, both private and public sector employers must produce more with less. One imperative of the growing pressure is to use workforces more productively, via work reorganization, motivation, domination, engagement, partnership and/or flexibility. Because unions seek power sharing or at least influence, employers may gravitate toward one of two approaches: labor-management partnership or union marginalization. The former occurs - when it does - at the firm level in Liberal Market Economies (LMEs) and at both firm and sector levels in Coordinated Market Economies (CMEs). The latter takes shape in both types of political economy in efforts to weaken union influence - through aggressive bargaining, union avoidance or outright union busting. Employers often pursue contrasting strategies in different locations, from partnership 
where unions are entrenched to determined avoidance where unions lack a strong presence or institutional protections.

In the face of employer pressure, unions respond in new or deepened partnership arrangements where possible, often on the basis of concession bargaining, and in countermobilization where union influence is challenged or excluded. In CMEs, labor typically relies on institutional anchors to negotiate the terms of change and to defend established social partnership relationships, often with concession bargaining and increasingly backed by rankand-file mobilization. In LMEs, unions typically accept firm-level partnership where it is offered or can be demanded - most often in a context of concession bargaining and management dominance - and pursue counter-mobilization of various kinds elsewhere.

\section{Labor Mobilization and the Logic of Participation}

The logic of participation thus takes different forms in different contexts for both employers and unions, in ongoing processes of negotiation and conflict. In a context of global liberalization and employer reform initiatives, much depends on union strength and institutional position. Relations of partnership, for example, typically crumble or lose meaning in the absence of strong union presence - in the long term in CMEs (with social partnership) and in the short-to- medium term in LMEs (in firm and plant-level partnership). In an era of broadly declining union influence, sustained participation between employers and unions thus depends to a large extent on labor movement revitalization. And given serious union decline in LMEs alongside a gradual weakening of institutional position in CMEs, labor revitalization appears likely to require a new period of activist mobilization.

The causal chain from globalization to sustained participation can be mapped out schematically as follows: 


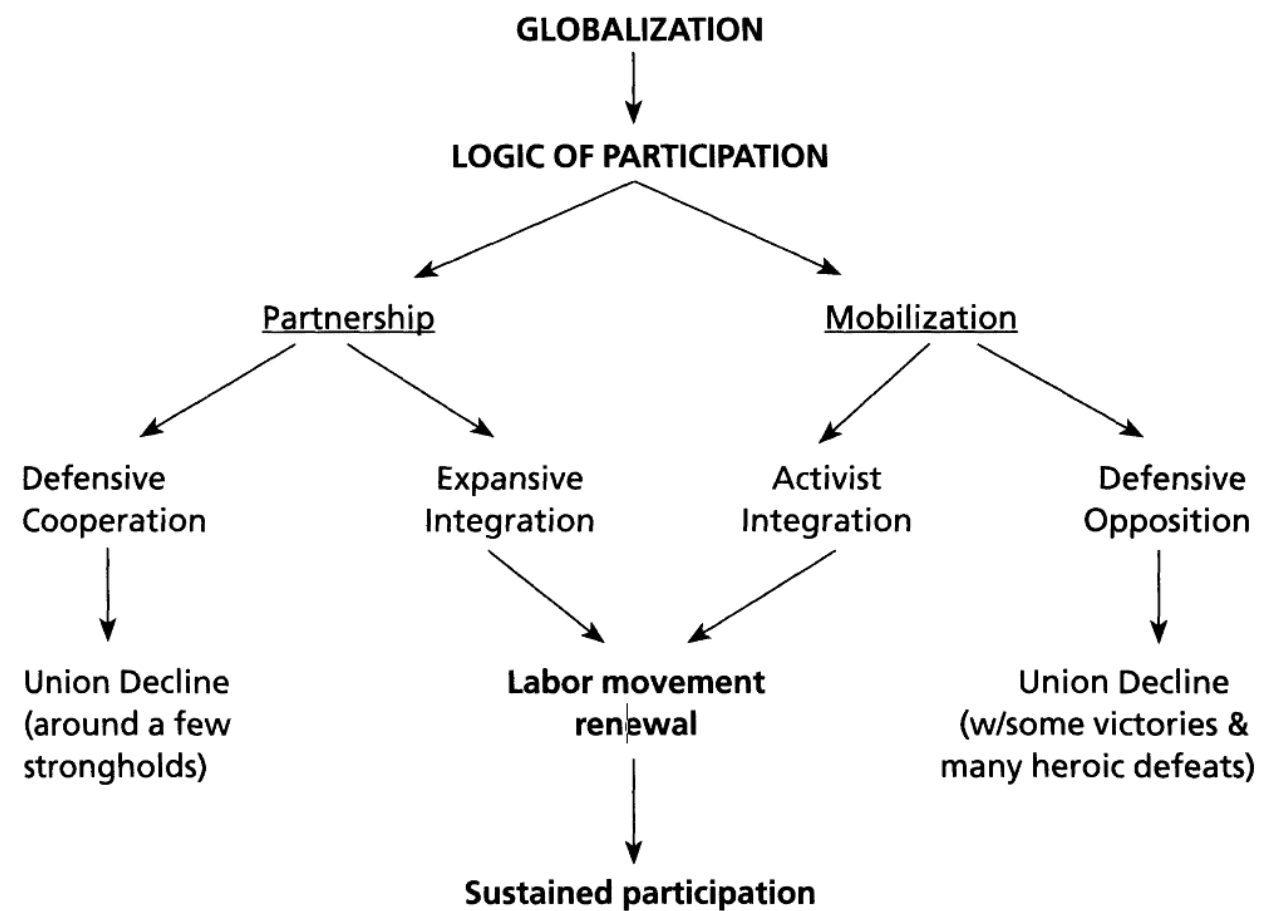

Thus the counter-intuitive argument: labor inclusion and institutional incorporation - and perhaps, in the long run, labor peace - depend upon innovative union strategies to mobilize pressure from the grassroots on up, at local, national and global levels. It is also clear that given contemporary circumstances unions and workers cannot mount the necessary counterpressure alone. Expanded coalition building thus becomes an essential element of renewed mobilization and sustained participation'.

\section{The Argument: Strategic Choice and Coalition Building}

The general, framing argument outlined above can be simplified along one dimension as follows: the pressures of global liberalization and its logic of participation drives an expansion of union coalition building. The causal chain runs from liberalization to escalating employer pressure of various kinds on workers and unions, resulting in destabilization of existing industrial relations and union responses. Depending on the strategic choices of labor leaders, union responses can be more or less traditional or innovative. While the former are typically defensive, the latter often involve grassroots mobilization and expanded coalition building, not only with other unions but with a range of other social actors as well.

Coalition building occurs at local, national and global levels, as unions find common interests and join in campaigns with churches, social movement groups, politicians and even employers for particular issues ${ }^{\text {ii }}$. Coalition building is important both for its reformist counterpressure on employers and governments and as an indicator for labor's shift from special interest group (especially in LMEs) to broad partisan force for the expansion of democratic voice and participation. Processes of innovation for both employers and unions, as well as 
institutional or substantive change (from public policy to work reorganization) can be more or less incremental or rapid, depending on circumstances and strategies.

The particular links in the causal chain examined here can be summarized in several propositions, with causation running as follows:

1. from strategic choice (rooted in organizational learning, reformed leadership, and a discovery or framing of common interests) and defining moment (including victory, defeat and/or organizational crisis) to sustained coalition buildings

2. from one coalition campaign to another $\bullet$, as networks of common interest and interaction develop in processes of spillover,

3. from campaigns to institution building, in cases where leaders and bridge builders in established organizations translate common interests and experience-based relationships into sustained coalitions capable of a range of strategies and tactics aimed at a variety of targets;

4. from coalition campaigns to observable outcomes, successes and failures, both for specific campaign results and for the expansion of union influence in politics, economy and society.

\section{Coalition Building: Types, Levels and Partners}

As global liberalization drives a new participatory impulse, unions press for labormanagement partnership where this is possible and increasingly for grassroots mobilization and expanded coalition building where partnership is not possible. For mobilization and coalition building, the targets are often employers who choose to weaken or exclude union participation. Ironically, as the cycle of protest escalates, the groundwork is established for a potentially virtuous circle that brings employers back in - both in firm and sector partnerships and in coalitions of common interest, such as local, national and even global campaigns for sustainable development. An example of such dynamics in offered in the labor-environmental case study below.

As unions seek allies, typical partners include environmental organizations, religious and human rights groups, local and national politicians, ethnic, racial and women's groups, immigrant rights advocates, and a variety of other activist groups based in civil society - from community organizers and consumer groups to gay and lesbian and in some cases even taxpayer groups iii. Employers may join coalitions earlier as in local 'smart growth' campaigns or later when coalition power is mobilized, or they may resist coalition demands, resulting either in campaign defeat or employer concessions (or some compromise in between).

Coalition types include events, campaigns and institutional consolidation (Tarrow, 2004). Events are one-time affairs such demonstrations, sit-ins and cross-country caravans. Campaigns are more sustained efforts over a longer time period, involving a multiplicity of possible tactics aimed a particular goal, such as immigration or citizenship policy reform, living wage campaigns, local economic development, and specific environmental or union organizing efforts. Working relationships based on events can 'spill over' into campaigns and vice versa, and either or both can result in institutional coalitions or organizations such as the Alliance for Sustainable Jobs and the Environment (ASJE) in the US or The East London Community Organization (TELCO) in the UK. When networks based on events and/or campaigns coalesce 
into organizations, new institutional presence generates ongoing opportunities for influence aimed at governments and employers as well as intervention in critical economic and political debates.

Coalition-based events, campaigns, organizations and their sustaining networks and strategies can focus at local, national or global levels - or some combination of the three. Especially important are the linkages among efforts at the three levels, as a product of strategic expansion, expanding networks and/or spillover from one campaign to another.

The case study presented below is from the US and demonstrates the causal processes including events, campaigns and organization building in rather remarkable coalition efforts based on a deepening relationship between the United Steel Workers and the Sierra Club. While this LME-based case is particular to the US, background research in another LME (the UK) and in two CMEs (Germany and Italy) indicates some parallel processes at work - with similarities and differences in choices, strategies and outcomes that can be explained in comparative analysis (Frege, Heery and Turner, 2004). A preliminary comparative perspective is offered at the end of this article, based on contrasting cross-national institutions and union strategies, as a basis for future research and analysis.

\section{Case study: United Steelworkers and the Sierra Club, 1999-2004}

Relations between labor and environmental groups have long been problematic, in the US as elsewhere. Fundamental differences are rooted in conflicts between environmental protection and job protection or creation. Increasingly, however, here and there at national and local levels as well as in global trade and development debates, common interests have been discovered and framed, resulting in coalition events, campaigns and in some cases organizations. In the case presented here, common efforts by the US-based United Steelworkers (USW) iv and Sierra Club have resulted in coalitions of all three types (events, campaigns and organizations) and at all three levels (local, national and global), with spillover resulting in movement up, down and across from all three types and levels.

In addition to specific local campaigns that brought labor and environmental activists together (Obach, 2004; Rose, 2000), a national framework for collaboration also developed in the 1980s and 1990s. In 1981 Ronald Reagan fired 11,000 striking air traffic controllers around the same time his Secretary of the Interior James Watt was launching a vigorous assault on environmental regulations. Since then, labor and environmental organizations have often come down actively on the same side in national politics: in presidential and congressional elections and notably in trade debates. Unions and environmental groups campaigned intensively if unsuccessfully against NAFTA in 1993, and more successfully against 'fast-track' legislation (giving the president virtual carte blanche to negotiate trade agreements) from 1997-1999 and against the Free Trade Area of the Americas (FTAA) from 2001-2003.

Growing national collaboration offered encouragement to leaders and activists in specific regions and campaigns. In this broadly supportive context, the United Steelworkers and the Sierra Club have developed surprisingly close relationships at both local and national levels, in alliances that have also brought numerous other unions and environmental groups aboard.

The defining moment in this coalition-building relationship came when the US Wand environmental groups joined forces against the Maxxam Corporation in 1998-1999. Maxxam is 
a multinational corporation that owns both Pacific Lumber and Kaiser Aluminum.

Environmentalists in the Northwest were fighting Pacific Lumber to preserve ancient forests at the same time that Kaiser Aluminum was engaged in a protracted lock-out against its USW organized workers. Once the Maxxam connection was made, the USW and environmental groups offered each other support, including a joint demonstration at the home of CEO Charles Hurwitz in February of 1999. Favorable settlements resulted from both campaigns. From the Maxxam struggles emerged a new organization: the Alliance for Sustainable Jobs and the Environment (ASJE), a national organization in which USW and the Sierra Club played key roles and were joined by a broad range of other labor and environmental groups (Rose, 2003) ${ }^{\mathrm{v}}$.

Several key elements appear in this early coalition-building process: the joint campaign against Maxxam; significant events including the high-profile demonstration at the Hurwitz home; the birth of a new organization as a framework for ongoing institutional relationships; and spillover from campaign to event to organization and from local to national levels. The antiMaxxam campaign would also turn out to be a defining moment for labor-environmental coalition-building centered around the USW and Sierra Club, launching a process that would deepen in subsequent campaigns with quite remarkable effects.

Most immediately, the new ASJE played a leading role in the labor-environmental coalition that splashed forth in world-wide headlines in the 'Battle of Seattle' in late 1999 (November 30-December 3) ${ }^{\mathrm{vi}}$. While 'teamsters and turtles' became journalist shorthand for the emerging alliance, key organizing roles were played by the USW along with the Sierra Club and Friends of the Earth, building upon a local coalition based on Seattle's revitalized labor movement and the area's strong environmental movement ${ }^{\mathrm{vii}}$. Of the 50,000 demonstrators, roughly 30,000 were brought out by labor and 20,000 by environmental groups - with additional support from human rights groups, development advocates and other NGOs from the US and abroad such as Oxfam and Jubilee 2000. With issues framed by ASJE and others, groups found common cause against the World Trade Organization (WTO) and its free-trade fundamentalism that privileged MNC trade and investment interests over environmental, citizen and worker rights, in global North and South alike.

From 1999 to 2003, ASJE grew, held national conferences and expanded the scope of its efforts, playing a leading role, for example, in the successful campaign against the FTAA including a cross-country caravan from Seattle to Miami in 2003 to rally support for demonstrations on the occasion of hemispheric negotiations for an FTAA trade agreement. As at the WTO demonstrations, the issue was free trade versus fair trade, in US-led negotiations that incorporated investor and corporate interests while neglecting labor and environmental standards. And this time US-based opponents were joined in the successful anti-FTAA campaign by the powerful opposition of southern governments, emboldened by the election of trade union and Workers Party leader 'Lula' as president of Brazil.

Throughout, the Steelworkers and Sierra Club have continued to play central roles in leadership and member mobilization for ASJE events and campaigns. In addition to national campaigns targeting trade negotiations in Seattle and Miami (and in Washington, DC and elsewhere), the Alliance gave important support to a growing number of local campaigns. These include successful labor-environmental campaigns against Oregon Steel Mills in 2003 (ASJE, 2003) and against AK Steel in Middletown, Ohio, in 2004 (Sierra Club Activist Resource, 2004) and the list of such cases since 1999 ranges across the country. 
In addition to fighting against trade agreements and corporate interests, ASJE and its member organizations have also joined campaigns to promote alternative models of economic growth - in various local and national efforts aimed at sustainable development or 'smart growth'. From Buffalo and Milwaukee to Houston, Los Angeles and Portland, labor and environmental groups have found common cause with community groups, local politicians and particular business interests to press for job creation that is environmentally friendly. In such campaigns, ASJE built upon emerging 'green labor' and environmental justice movements. As unions have broadened the framing of their own interests beyond short-term job protection, and environmentalists have moved beyond wilderness and whales to include a growing focus on social justice, ASJE played a leading role in bringing actors together in specific coalitions and campaigns.

Most significantly perhaps, the above chain of events, campaigns and coalition building has now given rise to a new organizational effort at the national level known as the Apollo Alliance ${ }^{\text {viii. }}$. Led again by the USW and Sierra Club, the new alliance was backed by a long list of labor unions and environmental groups. Announced in the spring of 2003, the goal is to promote a 10-year US\$300 billion energy research and development plan - to revitalize American manufacturing through advanced environmental technologies and production. Known as the Apollo Project, the multifaceted proposal calls for both large-scale job creation and clean energy. The plan calls for a nationwide commitment to renewable energy development - from hydrogen fuel cell technology to wind, biomass and solar power - as well as expanded rail and mass transit systems. The Apollo Alliance argues that new energy sources and breakthroughs in technology would promote sustainable development and at the same time create up to 3 million new jobs in manufacturing, construction, mass transit operations, energy research, and a range of related services. The long-term goal is to link job creation and renewable energy to a vision of economic and social vitality in a clean, prosperous society of the future.

More than a pipedream, the plan has substantial support in both House and Senate, with important elements incorporated into candidate John Kerry's plan for 'energy independence'. ${ }^{\text {ix }}$ At the Democratic Convention in Boston in July of 2004, a meeting of the Apollo Alliance drew a standing-room-only crowd of enthusiastic participants (Pope, 2004).

\section{From Maxxam to Apollo: Lessons for Coalition Analysis}

The USW and Sierra Club led a rapid progression from isolated campaigns at Pacific Lumber and Kaiser Aluminum in the late 1990s to established national coalitions capable of influencing national, local and corporate policy. Innovative strategic choices, spurred on at the start by a defining moment, set the stage for a dramatic sequence of events, campaigns and organization-building efforts. Common efforts spilled over into new coalition initiatives, from Maxxam to Seattle and Miami, from WTO and FTAA protests to the visionary Apollo Alliance. In an interdependent world economy, the locus of activity moved rapidly from the local (Maxxam) to the national and global (ASJE, Seattle and Miami), back and forth to specific local campaigns and the recently formed national Apollo Alliance.

Returning to the propositions presented earlier, the causal linkages can be filled in as follows based on the case study presented here: 
1. from strategic choice - when USW and environmental groups learned of each other's struggles against Maxxam, leaders and bridge builders found common interests and decided to join forces; and defining moment - joint demonstration at CEO's house followed by victories in both campaigns; to sustained coalition building ASJE;

2. from one coalition campaign to another, as networks of common interest and interaction developed in processes of spillover - from Pacific Lumber and Kaiser Aluminum to WTO/Seattle, to local campaign victories, FTAA/Miami and the Apollo Project:

3. from campaigns to institution building, as leaders and bridge builders in the USW and Sierra translated common interests and experience-based relationships into the ASJE and Apollo Alliance, and in so doing brought many other unions and environmental organizations into sustained coalitions; and

4. from coalition campaigns to observable outcomes, successes and failures - success at Maxxam; success at Seattle in raising the profile of global debates and credible opposition to the dominant neo-liberalism; success in both Seattle and Miami in blocking trade agreements lacking in meaningful labor and environmental standards; successes and failures in local campaigns depending on a variety of specific factors; success in bringing the Apollo Project to the table for national debate although failure so far to gain policy adoption or implementation.

One case study doesn't begin to constitute proof; rather it is suggestive of possible causal relationships. What we can say is that campaign results in this case have so far been more promising than one could have credibly predicted a decade ago. Union influence has expanded into new areas: promoting a 'blue-green' agenda that in some cases can block state and corporate initiatives viewed as unfavorable for labor and the environment, while at the same time developing a constituency for sustainable development at local and national levels. Whether such initiatives, led by USW and the Sierra Club in the cases presented here, can spill over into broader labor movement revitalization -including union membership growth and expanded influence in other areas of the political economy - remains to be seen.

Behind all this activity, including causal processes outlined above, lies the driving force of global liberalization and its logic of participation. As employers and governments raise the pressure, unions fight back defensively (as they originally did at Kaisers/Maxxam) or they innovate - in labormanagement partnerships or in activist mobilization, two contrasting but potentially complementary forms of enhanced participation. In many cases, including joint USW-Sierra Club campaigns described here, coalitions with other social actors can expand opportunities for rank-and-file participation, from demonstrations and caravans to grassroots mobilization. In short, global liberalization drives a logic of participation that includes member mobilization and coalition building, generating new strength and vision that may come full circle to include employers and governments in forward-looking processes of collaboration. This can happen at the firm or sector level or in local and national politics - in sustainable development coalitions such as the promising Apollo Alliance. 


\section{Comparative Coalition Building: A Framework for Analysis}

Based on one country case, cross-national comparative analysis is beyond the scope of this article. It is possible, however, to begin pointing toward a frame-work for comparison. The case presented here is based in the US, widely considered a paradigmatic liberal market economy. In Germany, equally recognized as a large country coordinated market economy suitable for comparison with the US, labor-environmental coalitions have developed in quite different ways, based largely on contrasting institutions and politics.

In the US, the ASJE can been conceptualized as a 'coalition of protest' expanding into a 'coalition of influence' ${ }^{\prime}$. Given labor's weak institutional protections, coalition building in the US typically begins as a protest phenomenon. In Germany by contrast, labor institutions incorporate unions more fully in the political economy, empowering unions to build coalitions of influence. Labor-environmental alliances, often including both employers and the state, have developed over the past 20 years in collaboration between unions and Greens, at national, local and especially at firm level. Common interests have developed in areas of advanced environmental technologies, clean factories, renewable energy sources, mass transit and 'green' cities. Such collaboration has been long term and stable in comparison to more contested, ad hoc American efforts.

On the other hand, coalition building remains a minor aspect of German union strategy, especially in comparison to developments in the US (Behrens, Fichter and Frege, 2003). Beyond long-term stable coalitions of influence, German unions see little reason for innovative coalition building based on activist mobilization. Yet German unions continue to face declining membership density and political influence. Innovators from inside the German labor movement find their initiatives opposed by traditionalists who rely on institutional position to defend past gains. In a period of union decline, strong institutions are arguably blocking needed innovations such as organizing and coalition building (Turner, 2003).

Thus contrasting institutions make innovative coalition building more or less likely as a significant strategy in union efforts at renewal of influence. But institutions are only part of the story. We find local unions innovating in sustainable development coalitions in Germany, just as we find traditional unions in the US avoiding coalition building. Strategic choice matters, including choices made by unions and union leaders. Steelworkers and Sierra Club activists have made choices over the past six years that push labor-environmental collaboration forward. Particular local and national leaders have promoted such innovations against the dominant postwar approach of more narrow interest advocacy. In similar fashion, although largely thwarted so far, innovators in German unions also push for revitalization strategies including expanded, mobilization-based coalition building. If and when they gain the upper hand in contested political processes inside unions, existing institutional anchors could well enhance potential gains rather than blocking innovation.

The US-German comparison offered here is sketchy, in need of research and analysis that examines coalition efforts in these and other countries, considers the effects of contrasting institutions, and seeks to sort out the range of choice faced by union leaders and activists. The claim here is that institutions matter, but at the same time the choices unions make also matter and are not predetermined by institutional arrangement. The gaps and details need to be filled in and the argument fleshed out and tested in further research and analysis. 


\section{Literature Reconsidered}

The case study-based analysis presented in this article is intended to contribute to the growing body of work on labor movement revitalization ${ }^{x i}$. Moving beyond existing literatures, the revitalization perspective emphasizes the possibilities for union innovation and renewal of influence against the weight of global liberalization. Case studies and comparative analysis help illuminate the conditions under which innovation is more or less likely to emerge, and more or less likely to succeed. Coalition building is one of the more prominent of contemporary innovation strategies, along with organizing the unorganized, political action, internal reform and international solidarity (Frege and Kelly, 2004). Findings from the USW-Sierra Club case and framing analysis offer insights into coalition activities - events, campaigns and organization building - and potential causal processes in the emergence of sustained coalitions, from strategic choice and defining moments to spillover and institutionalization.

Such concepts and causal processes may also apply to some extent to other strategy innovations, a possibility worth pursuing in future research and analysis. And cross-national comparative analysis can help sort out the relative importance of causal variables, including existing national institutions and strategic union orientations.

Most important, the USW-Sierra case makes clear that innovations in union strategy such as coalition building are possible and can develop broad significance, when unions under pressure find common interests and enter into collaboration with other social actors. Global liberalization is no inexorable force, but rather a contested process that can be credibly challenged by actors who innovate and collaborate.

This case study as well as many others examined in revitalization work should put to rest the argument that labor is an 'old social movement', of declining significance in contemporary conflict $^{\mathrm{xii}}$. By contrast, the 'transformation of industrial relations' perspective (Kochan, Katz and McKersie, 1986) is reinforced in its emphasis on strategic choice and fundamental change - but challenged in its firm-centric orientation that privileges employer strategy and union adaptation. What unions have or have not done in the past has everything to do with explaining union decline in recent decades (earlier, for example, in the US and later in Germany), while innovative strategies such as coalition building offer promise for the revitalization of union influence.

Also challenged is the firm-centric Varieties of capitalism' perspective, with its emphasis on stable national institutions, a marginal role for labor in LMEs and an incorporated but subordinate role in CMEs (Hall and Soskice, 2001). Industrial relations, however, are clearly contested in ongoing political processes only partly determined by existing institutions (Thelen, 2001). The argument offered in this article emphasizes contingent outcomes and possibilities for institutional change: declining institutional protections and union influence where innovation is avoided (as in contemporary Germany); labor movement revitalization and potential institutional reform where innovations such as sustained coalition building are pursued and developed. And innovative union strategies are especially promising when unions draw on their most important potential asset (the one that few other actors can match): the mobilization of participation by members and allied organizations, in coalition-led events, campaigns and institution building. 
In this regard, more interesting than static cross-national comparisons is a new amendment to the varieties of capitalism perspective, one that emphasizes institutional change (Streeck and Thelen, 2004). Here the focus is on gradual transformation, as actors cut into institutional openings in various ways, causing incremental institutional change (whether intended or not) whose effects accumulate over a period of years. This new literature so far seeks to explain the success of global deregulation over the past 25 years and in so doing suggests a potentially important contribution to contemporary debates. Revitalization work can contribute here in two ways. First, by examining the possibilities for gradual transformation to work the other way around, toward a more 'democratic globalism' in an increasingly contested world economy - as a result of innovative initiatives taken by unions and other actors at local, national and global levels. Coalition campaigns, for example, that slow the advance of MNCdriven free trade while at the same time building support for sustainable development - labor and environmentally friendly as part of an alternative approach to economic growth - may work incrementally over time to transform institutions and policies in a more socially oriented direction. In contested processes, coalition campaigns may also fail to make headway, and either way explanation is required. The other and perhaps more likely possibility is that coalition-led breakthroughs will come, if they do, in a context of crisis or a broader social movement cycle - a possibility that Streeck and Thelen suggest in arguing that deregulation comes incrementally whereas social rights are more likely to expand in periods of 'punctuation'.

\section{Implications}

Steelworkers-Sierra Club coalition efforts examined in this article indicate possibilities for labor movement revitalization in an era when unions are under great pressure at all levels. In the face of global liberalization, solidarity among social actors takes on new meaning and potential significance, in interrelated local, national and global campaigns. Forced into a logic of participation, unions may increasingly seek allies and mobilize members - in common efforts aimed at expanding democratic voice both within the firm and beyond. In current circumstances, sustained participation, with real influence at micro and macro levels, may only be possible in the context of expanded coalitions of mobilization. If 'a new world is possible', as World Social Forum activists argue, this is clearly unlikely in the absence of expanded participatory engagement by workers and citizens. Against great odds and likely failure, USWSierra Club coalition building offers an example of one possible avenue for reformist initiatives and sustained participation - at firm and sector, and at local, national and global levels.

\section{Acknowledgements}

For their comments and contributions to this article, many thanks to Russell Gorkin, lan Greer, Marco Hauptmeier, Heiwon Kwon, Glynis Ritchie and Sidney Tarrow. Funding for the research was generously provided by the Hans-Bockler-Stiftung, the School of Industrial and Labor Relations at Cornell University, and the US Department of Education. This article was originally prepared for presentation at the IIRA 7th European Congress Lisbon, Portugal, September 7-11, 2004. 


\section{References}

Alliance for Sustainable Jobs and the Environment (2003) 'EJAG, ASJE and USWA Defeat OR Steel', Green Worker 4(3)11.

Behrens, M., Fichter, M. and Frege, C. (2003) 'Unions in Germany: Regaining the Initiative?', European Journal of Industrial Relations o( 1): 2 5-42.

Brecher, J. and Costello, T. (1990) Building Bridges: The Emerging Grassroots Coalition of Labor and Community. New York: Monthly Review Press.

Bronfenbrenner, K., Friedman, S., Hurd, R. W., Oswald, R. A. and Seeber, R. L. (1998) Organizing to Win: New Research on Union Strategies. Ithaca, NY: ILR Press/Cornell University Press.

Cornfield, D. and McCammon, H. (2003) Labor Revitalization: Global Perspectives and New Initiatives. Amsterdam: JAI Press.

Fantasia, R. and Voss, K. (2004) Hard Work: Remaking the American Labor Movement. Berkeley, CA: University of California Press.

Frege, C. and Kelly, J. (2 004) Varieties of Unionism: Strategies for Labor Movement Renewal in the Global North. Oxford: Oxford University Press.

Frege, C, Heery, E. and Turner, L. (2004) 'The New Solidarity? Coalition Building in Five Countries', in C. Frege and J. Kelly (eds) Varieties of Unionism: Strategies for Labor Movement Renewal in the Global North, pp. 137-58. Oxford: Oxford University Press.

Greenhouse, S. (2003) Unions Back Research Plan for Energy. New York Times June 6, A20.

Halbfinger, D. and Banerjee, N. (2004) Kerry, Touring Missouri, Pitches 'Energy Independence' Plan. New York Times August 6, A12.

Hall, P. and Soskice, D. (2001) Varieties of Capitalism: The Institutional Foundations of Comparative Advantage. New York: Oxford University Press.

Hawken, P. (2000) 'On the Streets of Seattle', The Amicus Journal, Spring: 29-51.

Inglehart, R. (1977) The Silent Revolution: Changing Values and Political Styles Among Western Publics. Princeton, NJ: Princeton University Press.

Keck, M. and Sikkink, K. (1998) Activist beyond Borders: Transnational Advocacy Networks in International Politics. Ithaca, NY: Cornell University Press. 
Kelly, J. (1998) Rethinking Industrial Relations: Mobilization, Collectivism and Long Waves. London: Routledge.

Kochan, T. A., Katz, H. C. and McKersie, R. B. (1986) The Transformation of American Industrial Relations. New York: Basic Books.

Levi, M, and Olson, D. (2000) 'The Battles in Seattle', Politics and Society 28(3): 309-29.

Nissen, B. (2004) 'The Effectiveness and Limits of Labor-Community Coalitions: Evidence from South Florida', Labor Studies Journal 29(1): 76-89.

Obach, B. (2004) Labor and the Environmental Movement: The Quest for Common Ground. Cambridge, MA: MIT Press.

Pope, C. (2003) Ways and Means: A New Apollo Project. Sierra Magazine, September/ October, http://www.sierraclub.org/sierra/200309/ways.osp

Pope, C. (2004) We Are in Play. Field Notes, July 29, http://www.strategicignorance.com/fieldnotes/boi6.asp

Rose, F. (2000) Coalitions Across the Class Divide: Lessons from the Labor, Peace and Environmental Movements. Ithaca, NY: Cornell University Press.

Rose, F. (2003) 'Labor-Environmental Coalitions', WorkingUSA 6(4): 51-70.

Sierra Club Activist Resource (2004) The Planet Newsletter, 'updates', http://www.sierraclub.org/planet/20402/updates.asp

Streeck, W. and Thelen, K. (2004) 'Institutional Change in Advanced Political Economies'. Proceedings of the Conference of Europeanists, 11 March-13 March 2004, Chicago.

Tarrow, S. (2005) The New Transnational Activism. Cambridge: Cambridge University Press.

Thelen, K. (2001) 'Varieties of Labor Politics in the Developed Democracies' in P. Hall and D. Soskice (eds) Varieties of Capitalism: The Institutional Foundation of Comparative Advantage, pp. 71-103. New York: Oxford University Press.

Turner, L. (2003) 'Reviving the Labor Movement: A Comparative Perspective' in D. Cornfield and H. McCammon (eds) Labor Revitalization: Global Perspectives and New Initiatives, pp. 23-57. Amsterdam: JAI Press.

Turner, L. (2004) 'Globalization, Participation and the Renewal of the Labor Movement' in J. German and R. Marshall (eds) The Future of Labor Unions: Organized Labor in the $21^{\text {st }}$ Century, pp. 111-33. Austin, TX: University of Texas Press. 
Turner, L., Katz, H. and Hurd, R. (2001) Rekindling the Movement: Labor's Quest for Relevance in the 21st Century. Ithaca, NY: Cornell University Press.

\section{Voss, K. and Sherman, R. (2000) 'Breaking the Iron Law of Oligarchy: Union Revitalization in the American Labor Movement', American Journal of Sociology 106(2): 303-49.}

'An earlier formulation of this argument was presented in Turner (2004).

ii Union coalition building literature is in early stages. Significant contributions include Brecher and Costello (1990); Obach (2004) and Rose (2000).

iii Such coalitions are typically made possible by 'bridge builders' inside unions and their coalition partners. Undeveloped in this article (subsumed under 'strategic choice' and 'reformed leadership'), the concept is especially important for future research and analysis - building on useful work done so far (Brecher and Costello, 1990; Nissen, 2004; Obach, 2004; Rose, 2000; Voss and Sherman, 2000).

iv The official name is United Steelworkers of America (USWA), but will be referred to here in common parlance as USW or the Steelworkers.

${ }^{v}$ See the official web site at asje.org. One of the founding members of the ASJE was David Brower, perhaps the most prominent American environmental activist of the second half of the 20th century, a former president of both the Sierra Club and Friends of the Earth. Often at odds with unions around issues such as dam building, Brower told me in an interview shortly before he died that the growing labor-environmental coalition reflected in ASJE and the Battle of Seattle was the 'mother lode' he had searched for all his life.

vi On the Seattle demonstrations, see for example Hawken (2000) and Levi and Olson (2000).

vii The emerging labor-environmental alliance that took shape in the Seattle demonstrations built upon the bridge-building role of activist local leaders such as USW regional director David Foster and Ron Judd of the King County Central Labor Council.

viii See the official web site at apolloalliance.org and Greenhouse (2003); Pope (2003) and Pope (2004).

ix While emphasizing energy independence in part for national security (and political) reasons, Kerry's plan also called for clean energy-based manufacturing revival and greatly expanded research and development in hydrogen, solar and wind power (Halbfinger and Banerjee, 2004).

${ }^{x}$ See Frege, Heery and Turner (2004) on the distinction between coalitions of protest and coalitions of influence, in the context of cross-national comparisons that include the US and Germany. The authors also distinguish between vanguard, common cause and integrative coalitions; the coalitions considered here are of the common cause variety (see also Nissen, 2004).

${ }^{x i}$ See, for example, Bronfenbrenner et al. (1998); Cornfield and McCammon (2003); Frege and Kelly (2004); Kelly (1998); Turner, Katz and Hurd (2001) and Fantasia and Voss (2004).

xii That labor is an old social movement of declining relevance has been argued by 'new social movement' theorists such as Inglehart (1977) for the national level and more recently Keck and Sikkink (1998) for the international level. For a contrasting perspective that emphasizes transnational labor solidarity, see Tarrow (2004). 